\title{
Mitral valvuloplasty without support in children - Modified De Vega technique: case reports
}

\author{
Valvoplastia mitral sem suporte em crianças - técnica de De Vega Modificada: relato de casos
}

\author{
Magnus R. COELHO DE SOUZA*, Eduardo COELHO DE SOUZA*, Marcos Antônio Dantas de \\ ALMEIDA*, Adailton de Carvalho RESENDE*, Rogério PORCIONATO*, Ricardo MINGIREANOV*, \\ Rosangela Belbuche FITARONI*
}

RBCCV 44205-612

\begin{abstract}
We report on three cases of mitral regurgitation in children at ages of 7 months, 5 months and 10 years old. In two of them, the etiology was congenital and the other it was rheumatic. The surgical technique used was valvuloplasty without support using the modified De Vega technique isolated or associated with other procedures. One of the children was re-operated seven years after the first surgery. All the patients were rated New York Association Class III before surgery. Following the surgery they were at Class I with good outcomes. All patients survived, without complications. According with the literature, mitral regurgitation can be treated with mitral valvuloplasty without support or using other surgical techniques, with excellent outcomes. We report here on one more option for its treatment especially in children and adolescents. This technique is easily performed and it permits growth of mitral valve during life.
\end{abstract}

Descriptors: Mitral valve insufficiency, surgery. Mitral valve, surgery. Heart valve disease, surgery.

\section{Resumo:}

Relatamos três casos de insuficiência mitral em crianças (7 meses, 5 meses e 10 anos de idade), dois de etiologia congênita e um adquirida (reumática), em que realizamos valvoplastia sem suporte, utilizando a Técnica de De Vega Modificada isolada ou associada a outras técnicas. Uma das crianças foi reoperada sete anos após a primeira operação. Os pacientes evoluíram de classe funcional III para I imediatamente e apresentaram boa evolução clínica tardia.

Não houve óbito nessa pequena amostra. A insuficiência mitral pode ser tratada por valvoplastia mitral sem suporte com bons resultados imediatos tardios, o que já foi descrito na literatura por outras técnicas cirúrgicas e relatamos aqui mais uma opção para o seu tratamento, principalmente para uso em crianças e jovens, pois a técnica além de ser facilmente executável mostrou permitir o crescimento da valva mitral com o decorrer do tempo.

Descritores: Insuficiência da valva mitral, cirurgia. Valva mitral, cirurgia. Doença das valvas cardíacas, cirurgia

Work performed in the Hospital da Beneficência Portuguesa of São Paulo.

* From Instituto de D.C.P.E.J. Zerbini/Magnus Coelho de Souza. Correspondence address: Rosangela Belbuhe Fitaroni. Rua Maestro Cardim, n 1218 , apto 54. Paraíso. São Paulo, SP. CEP.: 01323-001. Tel: (11) 289.6730 / 3253.5022 R-1280 / 283.4015.

Fax: (11) 289.6730. E-mail fitaroni@aol.com 


\section{INTRODUCTION}

Congenital malformations of the mitral valve are complex lesions as a consequence of varying morphologic anomalies that occur and involve, generally, more than one of the valvular components [1,2].

Isolated congenital lesions, such as stenosis or mitral insufficiency, are rare, representing $1 \%$ of the congenital cardiopathies $[1,3,4]$.

Isolated congenital mitral insufficiency is uncommon, encountered in infancy associated with other cardiac defects, connective tissue disorders and in acquired inflammations, such as myocarditis, rheumatic fever, endocarditis and Kawasaki's disease, for example [4].

In congenital mitral stenosis, the flow obstruction results from morphologic anomalies at different levels [5-7]. In newborn babies it is attributed to congenital abnormalities of the mitral valve or of the subvalvar apparatus [8].

Mitral valvuloplasty became more divulged in the 1980s, especially in the USA.

The first mitral valve repair using a prosthetic ring was performed in 1968, in the Broussais Hospital in Paris by Carpentier. Mitral valve repair in patients with mitral regurgitation can be performed with the same operative mortality as mitral valve replacement and it is associated with a smaller incidence of thromboembolism, endocarditis and hemorrhages related to anticoagulation. This results in a better immediate and late ventricular function than valve replacement [9].

\section{CASEREPORTS, SURGICALTECHNIQUEAND RESULTS}

We report on three cases of mitral valvuloplasty for mitral insufficiency, two congenital and one rheumatic, in which we utilized a Modified De Vega technique (Figures 1A and 1B).

\section{CASE N ${ }^{0}$}

A 5-month female infant was diagnosed by echocardiograph with discreet mitral stenosis, significant

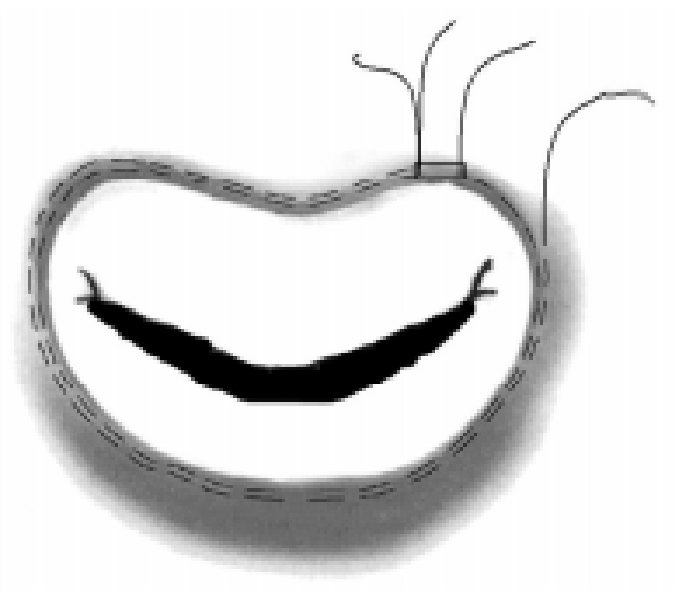

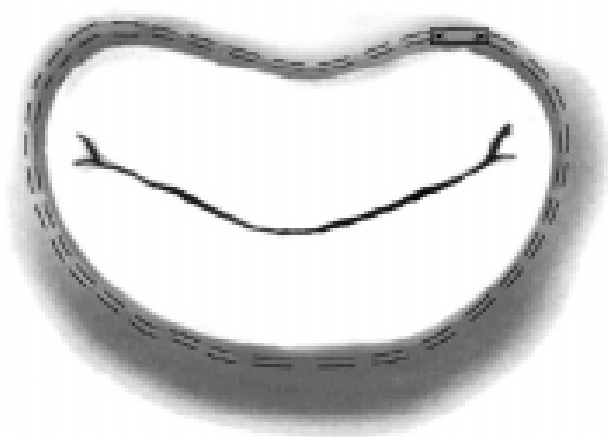

Fig. $1 A$ and $1 B$-Schematic design of the mitral valve during and after performing the Modified De Vega technique (Diagram based on the book of SOCESP Cardiology, 2nd volume, chapter 83, Pomerantzeff PMA et al.).

mitral insufficiency, significant aortic stenosis and discreet aortic insufficiency of a congenital etiology. She was submitted to cardiac surgery in functional class III.

Surgical Technique - Stenosis of the commissures of the mitral valve was slight, but the papillary muscles were long and penetrated into the atrial plane of the valve and had many chordae, some of which were abnormal. Papilectomy of both papillary muscles and commissurotomy were performed. The valvar annulus was very big and the redundant anterior cuspid made prolapse of the medium or Carpentier A2 zones into the left atrium. Plasty of the anterior mitral cuspid was performed, with some anchoring sutures of Teflon and following this we sutured two complete times around the mitral valve using continuous sutures (Modified De Vega), evidently diminishing its size. We also performed plasty and commissurotomy of the aortic valve.

In the immediate post-operative period the patient presented with an accentuated reduction in the cardiac area and pulmonary congestion monitored by comparing the pre-operative (Figure 2) and immediate post-operative (Figure 3) thoracic radiograms.

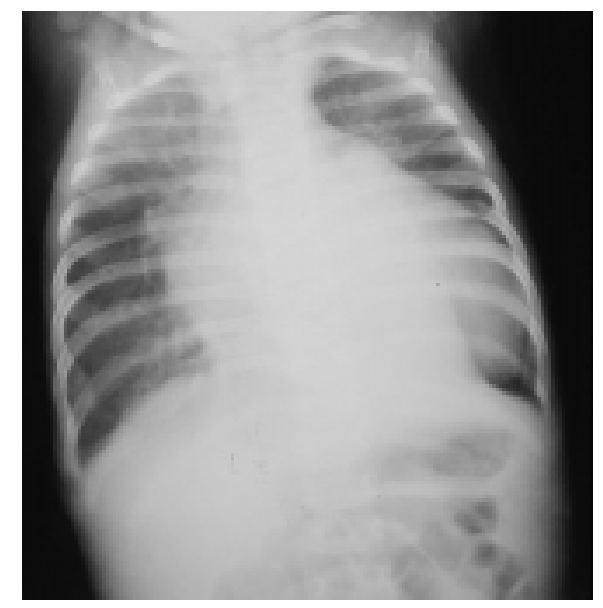

Fig. 2 - Pre-operative radiography of the thorax, showing cardiomegaly and significant pulmonary hyper-flux. 


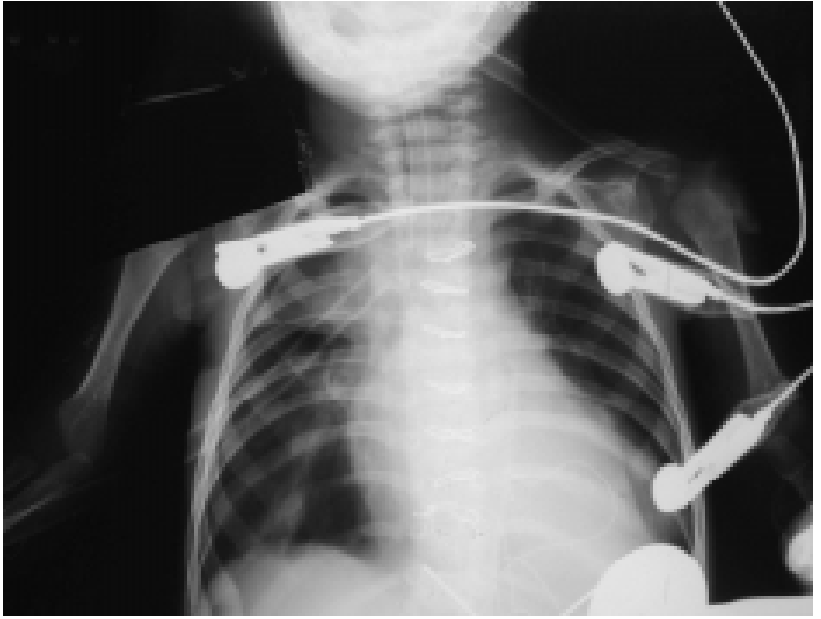

Fig. 3 - Radiography of the thorax in the immediate post-operative period, showing an accentuated reduction in the cardiac area and of the pulmonary flow.

\section{CASE $\mathbf{N}^{\circ} 2$}

A ten-year-old female infant with echocardiographic diagnosis of severe mitral insufficiency of a rheumatic nature was surgically treated.

Surgical Technique - During the surgery it was observed that the mural cuspid of the mitral valve had retraction and was thick and, near to the anterior commissure, there was a third commissure. The anterior cuspid was redundant and some bundles of chordae were long and thin. The valvar annulus was dilated and the insufficiency was caused by the third commissure, which protruded into the left ventricle. Two continuous sutures were made completely around the annulus (Modified De Vega technique), so reducing its diameter.

There was a good improvement in the mitral insufficiency and an accentuated reduction in the diameters of the left chambers as can be seen comparing the pre-operative (Figures $4 \mathrm{~A}$ and $4 \mathrm{~B}$ ) and post-operative (Figures $5 \mathrm{~A}$ and $5 \mathrm{~B}$ ) echocardiograms.

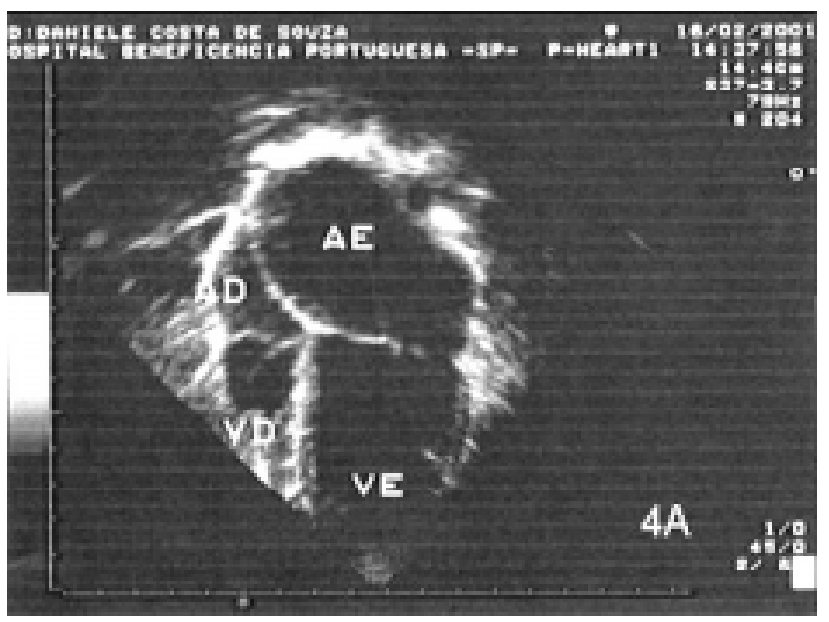

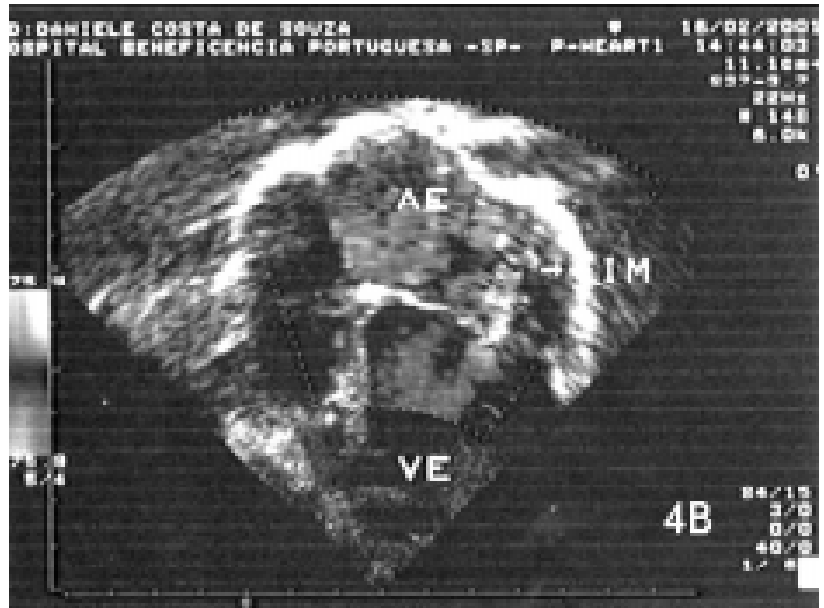

Fig. $4 A$ and $4 B$ - Pre-operative 2-dimensional color echocardiogram showing moderate mitral insufficiency and an significant increase in the left heart chambers.
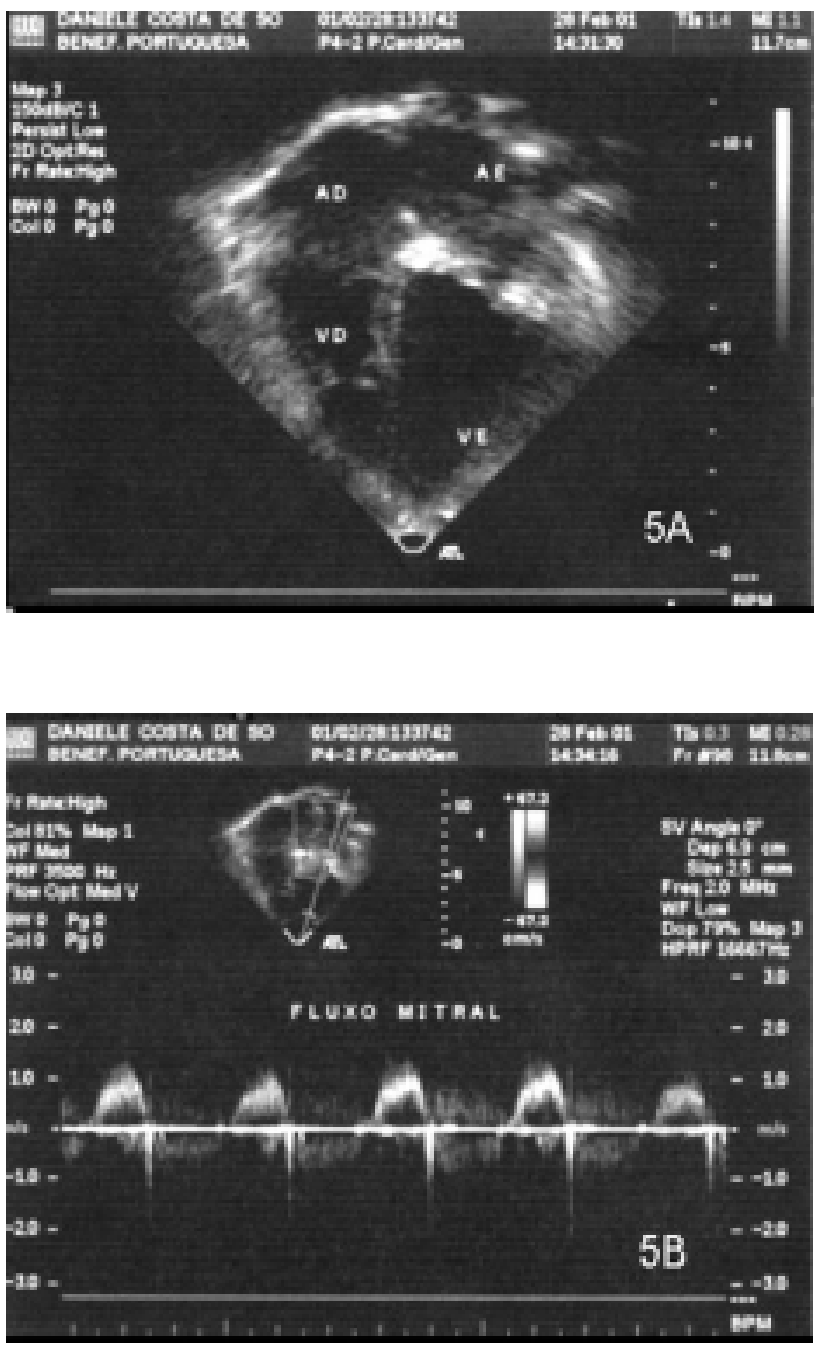

Fig. 5A and 5B-2-dimensional color echocardiogram on the $8^{\text {th }}$ post-operative day after correction surgery showing an accentuated reduction in the right chambers and the mitral insufficiency. 
Currently the child is functional class I, without the use of drugs and with discreet mitral insufficiency evidenced by echocardiogram.

\section{CASEN $N^{\circ}$}

A seven-month male infant with an echocardiographic diagnosis of congenital interventricular communication and significant mitral insufficiency (Figure 6) underwent surgery in functional class III. the threads, which were used for the circular suture line were removed, and it was verified that the valvar annulus and the leaflets were sited some millimeters below the fibrous annulus which was resected, freeing the mitral annulus. There was no stenosis of the commissures and the leaflets were of a good size.

It was clear that the circular suture line had formed the fibrous ring above the valvar annulus, allowing it to grow whilst the fibrous ring caused mitral stenosis.

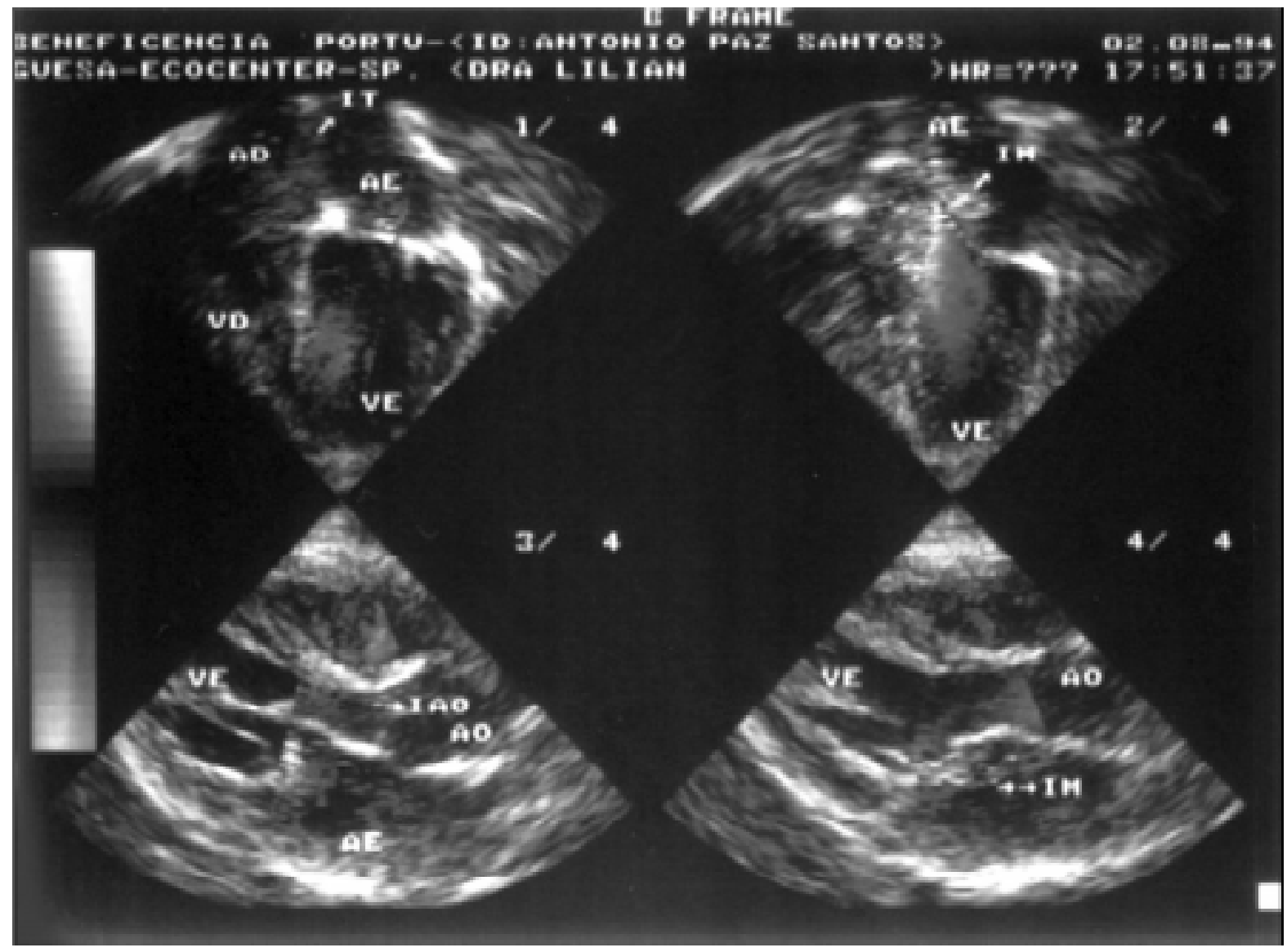

Fig. 6 - 2-dimensional color echocardiogram, demonstrating moderate mitral insufficiency and subaortic interventricular communication.

Surgical Technique - The interventricular communication was corrected with a Teflon patch fixed at seven points and the mitral valve was evaluated which presented with severe mitral insufficiency with the valvar annulus dilated and long chordae, allowing prolapse of the anterior cuspid.

Two continuous suture lines completely around the valvar annulus were made which were tied using Teflon, reducing its size and allowing a good coaptation of the leaflets (Modified De Vega technique).

Seven years after the surgery, the child returned with the diagnosis of double mitral lesion (predominance of mitral stenosis), requiring reoperation.

During the surgery, the presence of fibrous annulus was observed over the mitral valve, constituted by the circular suture line made in the first surgery. The Teflon patch and
Today, eight years after the second surgery, the patient has functional class I without mitral dysfunction, a fact which reinforces the use of plasty without the support of the mitral valve whenever possible and principally in children, as this may allow development of the mitral valve.

\section{COMMENTS}

To perform mitral valvuloplasty it is important to understand its anatomy.

The most important indication is mitral insufficiency due to rupture or extension of the chordae tendineae in patients with myxomatosis degeneration, but it is also indicated in cases of rheumatic fever, ischemic mitral insufficiency, congenital lesions among others [10]. 
In the majority of published series there is a predominance of non-rheumatic lesions $[11,12]$ and few reports are related to annuloplasty without support $[13,14]$.

The ideal treatment in valve disease is that which corrects the anatomic lesions by means of conservative procedures $[2,15,16]$, permitting hemodynamic normalization.

Rheumatic disease is one of several causes of mitral insufficiency and it is, without doubt, the most frequent [17].

The necessity of surgical intervention is common in the young population, independently of the etiology, where bioprosthetic implantation tends to suffer from an early degenerative process [8] and the metallic prostheses demand effective and permanent anticoagulation, which in many cases is impossible.

Mitral valvuloplasty currently is the preferred procedure for the correction of mitral insufficiency [17], and its use should be encouraged [18] mainly with children.

The outcomes are low operative mortality ( 0 to $4.3 \%$ ), an improvement in ventricular function due to the preservation of the papillary muscles, a low incidence of reoperation and lasting hemodynamic and symptomatic improvements [1,9,19].

Mitral valvuloplasty, using the Modified De Vega technique, apart from permitting normal anatomic growth of the valve, proves, in our experience, to be an excellent method of correcting mitral insufficiency in children.

\section{BIBLIOGRAPHIC REFERENCES}

1. Carpentier A. Valvuloplastia/anuloplastia. In: Harlan BJ, Starr A, Harwin FM, editores. Manual ilustrado de cirurgia cardíaca. Rio de Janeiro: Revinter; 2000. p. 115-22.

2. Carpentier A. Congenital malformations of the mitral valve. In: Stark J, de Leval M, editors. Surgical for congenital heart defects. Philadelphia: WB Saunders, 1994. p.599-614.

3. Medeiros Sobrinho JH, Fernandes V, Cunha S. Anomalias da valva mitral. Cardiopatias Congênitas. São Paulo: Sarvier; 1990. p.386.

4. Baylen BG, Eriley JM. Diseases of mitral valve. In: Adams $\mathrm{FH}$, George C, editors. Heart disease in infants, children and adolescents. $5^{\text {a }}$ ed. Baltimore: Williams \& Wilkins; 1995. p.51626.

5. Anderson RH, Tynan M, Shinebourne EA, Macartney FJ. Pediatric cardiology. Edinburgh: Churchill-Livingstone, 1984. p.1023. 19.
6. McGiffin DC. Surgery of the mitral valve in children. In: Wells FC, Shapiro LM, editors. Mitral valve disease. Oxford: Butterworth-Heinemann; 1996. p.149-59.

7. Embrey RP, Behrendt DM. Congenital abnormalities of the mitral valve. In: Bave AE, Geha AS, Laks H, Hammond GL, Naunheim KS, editors. Glenn's thoracic and cardiovascular surgery. $6^{a}$ ed. vol II. Stanford: Appleton \& Lange; 1996.

8. Santana MVT. Cardiopatias congênitas no recém-nascido: diagnóstico e tratamento. São Paulo: Atheneu; 2000. p. 37782 .

9. Carpentier A, Deloche A, Dauptain J, Soyer R, Blondeau P, Piwnica A et al. A new reconstructive operation for correction of mitral and tricuspid insufficiency. J Thorac Cardiovasc Surg $1971 ; 61: 1-13$.

10. Pomerantzeff, PMA. Plástica da valva mitral. Revista do INCOR 1997; 2: 38-42.

11. Cosgrove DM, Chavez AM, Lytle BW, Gill CC, Stewart RW, Taylor PC et al. Results of mitral valve reconstruction. Circulation 1986;74(3 Pt 2):I82-7.

12. Deloche A, Jebara VA, Relland JY, Chauvaud S, Fabiani JN, Perier P et al. Valve repair with Carpentier techniques: the second decade. J Thorac Cardiovasc Surg 1990; 99:990-1002.

13. Arruda MB, Moraes CR, Lagreca JR, Escobar M, Victor EG, Cavalcanti IL. Anuloplastia mitral . Arq Bras Cardiol 1974; 27 (Supl1):32 (Resumo).

14. Pomeranzeff PMA, Amato M, Stolf NAG, Marcial MB, Grinberg M, Pileggi F et al. Experiência com plástica de valva mitral. Arq Bras Cardiol 1985; 45 (Supl 1):156 (Resumo).

15. Chauvaud S, Perier P, Touati G, Relland J, Kara SM, Benomar $\mathrm{M}$ et al. Long-term results of valve repair in children with acquired mitral valve incompetence. Circulation 1986; 74(3 Pt 2): I104-9.

16. Sulayman, R, Mathew R, Thilenius OG, Reploge R, Arcilla RA. Hemodynamics and annuloplasty in isolated mitral regurgitation in children. Circulation 1975; 52:1144-51.

17. Bordignon S, Kalil RAK, Sant'Anna JRM, Prates PR, Pereira EM, Nesralla IA. Resultado clínico tardio de anuloplastia mitral sem suporte em crianças e adolescentes. Rev Bras Cir Cardiovasc, 1996, 11:263-9.

18. Gerola LR, Pomerantzeff PMA, Pêgo-Fernandes PM, Stolf NAG, Barbero-Marcial M, Ebaid M et al. Cirurgia valvar em crianças e jovens: resultados de 131 casos. Rev Bras Cir Cardiovasc 1990; 5:187-94.

19. Carpentier A. Cardiac valve surgery: the "French correction". J Thorac Cardiovasc Surg 1983; 86: 323-37. 